\title{
Celebrity Physical Attractiveness Effect on Consumer Buying Behavior
}

\author{
Rizwan Khalid *) \\ Tehreem Yasmeen **)
}

\begin{abstract}
Nowadays, the use of celebrity as brand endorsements is increasing. Celebrity is considered to be the fastest and safest way for a brand to develop an association and a bond in consumer minds. This study aimed to analyze the impact of a celebrity physical attractiveness on consumer buying behavior. This study only focuses on the buying intention of mobile phone product. Data was gathered from college (both private and public) undergraduate by questionnaires with an individual's age between 17 to 30 years as the target respondent. The reason in selecting those students with specific age is because they are the target consumer of the specific product that has been chosen as the research object. The researcher used simple random sampling as a sampling technique with 376 respondents and regression analysis is used to model the relationship between variable. This study concluded that there is a positive impact between the physical appearance of celebrity to purchase intention. There are a no different perception from gender, ages, institution type, and education background point of view regarding the attractiveness of celebrity physical and their intention to buy.
\end{abstract}

Keywords: Celebrity Endorsement; Physical Attractiveness; Purchase Intention

\section{INTRODUCTION}

\subsection{Research Background}

Today advertisements have made the world more vibrant and hectic through various communication of marketing. It is difficult to get consumer attention. In Pakistan, since the market of mobile phone is increasing, there are many brands used an advertisement to compete in capturing consumer attention. There are different approaches used for mobile phone advertisement, but celebrity endorsement is one of the most effective approaches (Nabel, 2014). Celebrity endorsement can bring their fans into consumers, or even convert them into the customers of the advertised product or brand. Partnering with the right celebrity will help the brand generate interest and intended responses like building the trust and relationship (Pandey, 2011). Celebrity endorsed commercials can cause more positive attitude (Gan, 2006), persuasive (Gaied \& Rached, 2010), likeability, and purchase (Parmar \& Patel, 2015) While unfamiliar celebrity endorsement had a little impact in persuading consumer make a to purchase (McCormick, 2016). Advertisers use celebrities to build and relate the brand or product image with the celebrity's lifestyle. The use of celebrity as a marketing gimmick in advertising program become popular nowadays in Pakistan (Ghani \& Kakakhel, 2011). In this study, researcher only focuses on physical attractiveness attribute of celebrity endorsement since attractive endorser is more effective in influencing purchase intention in high involvement product (Phau \& Lum, 2000).

\subsection{Research Problem}

Based on the research background, the problem statement in this study is; what is the effect of the physical attractiveness of celebrity endorsement toward the buying behavior (purchase intention) of students for mobile phone brands? 


\subsection{Research Purpose}

The purpose of this study is to examine the effect of celebrity physical attractiveness toward buying behavior (purchase intention). This influence has not been completely investigated in earlier research in a similar circumstance, and this study investigates it empirically. Also, this study is conducted in the field of mobile phone segments, so the result of this research will help to judge how much effective the use of physical attractiveness celebrity in the mobile phone industry.

\section{THEORETICAL FRAMEWORK AND HYPOTHESES DEVELOPMENT}

\subsection{Celebrity Endorsement}

The concept of celebrity endorsement is not a new one companies are using this concept from hundreds of years, and still, this idea is working. According to Andrews \& Shimp (2017) nearly $25 \%$ commercials are of celebrity endorsement and in South Asian countries such as Pakistan and India advertisements depends on celebrity endorsement for effective influence and to generate heavy sales (Anjum, Dhanda, \& Nagra, 2012). A lot of advancement is coming in this new world of advertising so to create a visible or evident communication and to capture the diverting attention of viewers celebrity's glamour, and appeal is prerequisites (Rafique \& Zafar, 2012). Celebrities don't mean the film stars only they could be from different fields like singers, sportsman, doctors, barristers, etc. with well-known generous personalities. They all can build and sustain a strong communication between the customers and brand to get a superior brand positioning in the customer eyes (Jamil \& Rameez ul Hassan, 2014). It is obvious that celebrity endorsement builds evident influence on the mind of the customer, but to what degree is uncertain or it may be positive or negative.

When we discuss advertisement of mobile phone, the celebrities endorsed commercials are capturing more customer attention as compared to a new or unrecognized face. To promote any advertisement, the main part is attractiveness because of these celebrities are endorsed and favored to get full glamour appearance and to get high audience viewership. Now you can see a lot of local brands are endorsed by foreign or Indian celebrities who directly affect the factor that is attraction or celebrity appeal. But it may also deviate the viewer attention from the brand the celebrities are promoting because the viewers only remember the celebrities face instead of the name of the product. It creates a negative impression on the customer's attitude (Pandey, 2011). The companies are positioning their mobile phone brands with well recognized and widely acceptable celebrities to develop a high level of trust in customers. It is founded that trustable personalities are more favored in this perspective. The customers viewed the celebrities as the family member and when they watch them promoting a specific brand and committing about that brand customers want to get it and experience that brand because of their supposed family member commitment.

Certified celebrities such as famous doctors, engineers, designers, economists, and barristers are supposed to most preferable for developing a relationship in between brand and celebrity because there is less risk involved due to their experience and profession (McCracken, 1989). Amid most recent ten years it was seen that prime time promotions are contained up of celebrities based advertisement around $65 \%$. But now it is observed that for the broadcast of mobile phones, $85 \%$ of advertisers are using celebrity endorsement (Schiffman, Kanuk, \& Hansen, 2008). In Pakistan, the first established mobile manufacturing brand was Motorola that initially invested in advertising except for celebrity endorsement. Then, Nokia similarly advertises its brand with no celebrity endorsement. After this, the third brand was Sony Ericson that was come into the market in 2003 without the concept of celebrity endorsement. The initial brand ambassador of mobile phone brand was Iman Ali and Shan which endorse blackberry and after it other brands marketers also start using celebrities in their advertisements (Schiffman, Kanuk, \& Hansen, 2008). 
Celebrities are defined as popular personalities; rising film stars sports Heros and trending TV actors, which can become a reference group for the viewers (Schiffman, Kanuk, \& Hansen, 2008). In order to create some significance, mindset, and behavior of the viewers, the celebrities can serve as a reference that why they are known as the reference group. A reference group also provide suggestion to customers in their buying behavior (Schiffman, Kanuk, \& Hansen, 2008). Because celebrity endorsement is beneficial for the market, two theories are explained one is effectiveness of celebrity endorsement by Ohanian (1990) estimation scale and other is the congruity of celebrities and item under the hypothesis of meaning transfer procedure of McCracken (1989).

Joseph (1982) viewed this research with a new angle not only personality traits, but he also investigated how much change can be made on the opinion, evaluation of product and other effective factors due to the personality of attractive endorsers. He finds out endorsers who are considered by consumers more attractive will create a big influence on products which are endorsed. According to Kahle \& Homer (1985), likeability and attractiveness of a celebrity can change the attitudes of consumers towards the advertisements in a positive way and also for the product. Consumers also had high purchase intentions for the advertised product. On the other hand, Baker \& Churchill (1977) found an evaluation of product can be done positively by using attractive endorser, but attractiveness is not too much effective in the case of developing strong purchase intentions. Moreover, Caballero, Lumpkin, \& Madden (1989) state that by using attractive endorsers, there is no cause on the effectiveness of advertising. In Advertisements for mobile Phone, new or unknown faces are used less as compared to the celebrity-based advertisements. Behind the story of any commercial attractiveness is become the major building block in order to make the product presentation more glamorous. Now many attractive foreign celebrities are endorsed for different local brands but few times instead of building the image of the brand the foreign celebrities get more attention and put a negative impression on the buying behavior of customer (Pandey, 2011).

\subsection{The Effect of Celebrity Physical Attractiveness Toward Purchase Intention}

An attractive and decent appearance is the usual concept that influences viewers to get something (Reingen \& Kernan, 1993). Marketers use visual elements to capture the market and create a positive buying behavior in customers (Clow, James, Kranenburg, \& Berry 2006). A lot of previous research works find that physical outlook of a celebrity was an important and talkable element (Baker \& Churchill, 1977; Joseph 1982; Kahle \& Homer, 1985; Winham \& Hampl, 2008).

Physical appearance is important because people are influenced by endorsed celebrities looks and style and can influence their buying behavior. As famous Indian people like Bollywood stars uncovered (versatile by Katrina) themselves by utilizing sensual looks and consideration catching dresses in Ads which grows more enthusiasm towards inverse sexual category and such appearance makes them more alluring and less demanding to review. Then again, Pakistan celebrities are having their particular significance and embraced inside social restrictions and religious points of confinement.

In advertisements for mobile phone, new or unknown faces are used less as compared to the celebrity-based advertisements., Behind the story of any commercial attractiveness is become the major building block in order to make the product presentation more glamorous. Now many attractive foreign celebrities are endorsed for different local brands but few times instead of building the image of the brand the foreign celebrities get more attention and put a negative impression on the buying behavior of customer (Pandey, 2011).

When we talk about celebrity endorsement, both the celebrity and brand are having a group of information knots that are stored in the mind of the consumers (Till, 1998). These association 
groups also include consumers intention regarding both brand and endorsers (Till \& Busler, 2000). Research demonstrates consumer shape a stereotype about people who are physically Kahle \& Homer (1985) likeability and attractiveness of a celebrity can change the attitudes of consumers towards the advertisements in a positive way and also for the product. Consumers also had high purchase intentions for the advertised product. On the other hand, Baker \& Churchill (1977) found the evaluation of product can be done positively by using attractive endorser, but attractiveness is not too much effective in the case of developing strong purchase intentions. Moreover, Caballero, Lumpkin, \& Madden (1989) states that by using attractive endorsers, there is no cause on the effectiveness of advertising. In Advertisements for mobile phone, new or unknown faces are used less as compared to the celebrity-based advertisements. Behind the story of any commercial attractiveness is become the major building block to make the product presentation more glamorous. Now many attractive foreign celebrities are endorsed for different local brands but few times instead of building the image of a brand the foreign celebrities get more attention and put a negative impression on the buying behavior of customer (Pandey, 2011).

Therefore, the hypothesis proposed in this study is;

$\mathrm{H}_{1}$ : The physical attractiveness of celebrity have a significant effect on consumer buying behavior.

\section{RESEARCH METHOD}

\subsection{Research Design}

This research is basic and quantitative. So, the data will be collected with the help of a questionnaire to find out the perception of respondent toward the celebrity physical attractiveness and their intention to purchase. This research used regression to analyze the effect of physical attractiveness toward buying behavior.

\subsection{Population and Sample}

Data was gathered from college understudies by questionnaires with an individual's age between 17 to 30 years as the target respondent. The reason in selecting those students with specific age is because they are the target consumer of the specific product that has been chosen as the research object Researcher used simple random sampling as sampling technique. Total population in this study is 16868 (consist of 14459 Multan public institutes students and 2409 Multan private institutes). Therefore, the suitable sample size for 16868 total population is 376 (Krejcie \& Morgan, 1970).

\subsection{Research Framework}

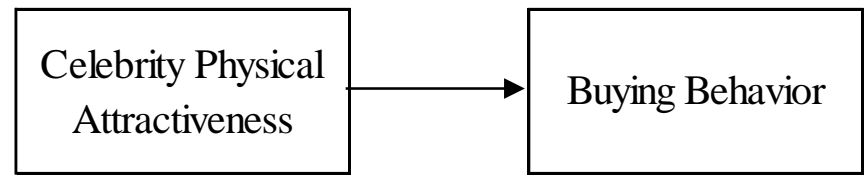

Picture 1 Research Framework 


\section{RESEARCH RESULT AND ANALYSIS}

\subsection{Descriptive Analysis}

The information of respondent profile was gathered from the respondents of the public institutions is composed up of $63 \%$, and they are 237 in number while the number of respondents of the private institute is 139 which make $37 \%$ out of $100 \%$. The majority of respondent in this research are 2125 years old, male, and bachelor student.

Table 1 Respondent Profile

\begin{tabular}{|c|c|c|}
\hline Category & Total & Percentages (\%) \\
\hline \multicolumn{3}{|l|}{ Sex } \\
\hline Male & 207 & 55,1 \\
\hline Female & 169 & 44,9 \\
\hline \multicolumn{3}{|l|}{ Age } \\
\hline $16-20$ years old & 112 & 29,8 \\
\hline $21-25$ years old & 192 & 51,1 \\
\hline$>25$ years old & 72 & 19,1 \\
\hline \multicolumn{3}{|l|}{ Institution } \\
\hline Public & 237 & 63 \\
\hline Private & 139 & 37 \\
\hline \multicolumn{3}{|l|}{ Education } \\
\hline Bachelor & 224 & 59,6 \\
\hline Master & 124 & 33 \\
\hline MPhill & 28 & 7,4 \\
\hline
\end{tabular}

Source: Primary Data Processed, 2018

\subsection{Validity and Reliability}

Table 2 Pearson Correlation

\begin{tabular}{|c|c|c|c|c|}
\hline No & Item & Pearson Correlation & Sig. (1-Tailed) & Decision \\
\hline 1 & PhysicAtt. & 0,533 & 0,000 & Valid \\
\hline 2 & BuyBhv & 0,533 & 0,000 & Valid \\
\hline
\end{tabular}

Source: Primary Data Processed, 2018

Table 2 explains that due to the $r$-value $(0,533)>r-$ table $(0,101)$, it can conclude that all item questionnaire proposed in this study is valid. There was no need to delete any item as all the values of alpha for each variable is more than 0,60 .

\subsection{Research Analysis}

Table 3 shows that the model has $\mathrm{R}^{2}=0,623$; this means that $62,3 \%$ of the variation in buying behavior is explained by independent variables (Physical Attractiveness). The significance level is 0,000 that is less than 0,05 . Therefore, the null hypothesis will reject and alternative hypothesis will accept that is buying behavior is positively associated with Celebrity Physical Attractiveness. This likewise implies the connection be tween's dependent variable and independent factors are measurable impressively, and the regression model is relevant. The applicable regression model involves that every single autonomous variable is clarifying that there is a positive and noteworthy association with buying behavior (dependent variable). 
The regression coefficient for physical attractiveness $\beta^{2}=0,012$ that means one unit increase in physical attractiveness boost 0,012 percent buying behavior of students if other variables remain constant. The t-test value is 0,255 , which is positive and significant at 0,019 means that there is a significant effect of the physical attractiveness of celebrity toward their buying behavior.

Table 3 Regression Result

\begin{tabular}{|l|c|c|c|c|}
\hline \multicolumn{1}{|c|}{ Variable } & $\begin{array}{c}\text { Regression } \\
\text { Coefficient }\end{array}$ & $\mathrm{t}_{\text {test }}$ & Sig. & Decision \\
\hline Physical Attractiveness (X) & 0,013 & 0,225 & 0,019 & Significant \\
\hline Constant & 0,501 & 5,508 & 0,000 & Significant \\
\hline $\mathrm{R}$ & \multicolumn{3}{|c|}{0,789} \\
\hline$R$ square & \multicolumn{3}{|c|}{0,623} \\
\hline $\mathrm{F}_{\text {test }}$ & \multicolumn{3}{|c|}{0,000} \\
\hline Sig. F & \multicolumn{3}{|c|}{376} \\
\hline $\mathrm{N}$ & \multicolumn{3}{|c|}{ Buying Behavior (Purchase Intention) } \\
\hline Dependent Variable & \multicolumn{3}{|c}{} \\
\hline
\end{tabular}

Source: Primary Data Processed, 2018

\subsection{Research Discussion}

There were a lot of studies within the discipline of the credibility of the movie star in the marketing. Consequences of the investigate transfer to writing in numerous viewpoints. In the first place, famous people Endorsement is fundamental for the gatherings to catch the consideration in their buyers because the groups of onlookers are spurred by utilizing the celebs in eagerness to purchase. We affirmed that the validity of the endorser is numbered to watcher/respondent/purchaser/client to search for a chose item. This believability now not just influences the psyche of buyers to purchase the item yet furthermore to expand a worthwhile verbal in regards to the logo being empowered with the guide of the over the top validity whiz. Even though the literature reflects the desirable effect of celebrity endorsement in many areas, this study furthermore indicates that this relationship of celebrity endorsement also affects the student's behavior of buying in Multan region. This study not only fills the research gap but also improves the understanding to realize the relation of celebrity endorsement and buying behavior of students in broad-spectrum. Majority of time viewer is engaged by the physical attractiveness of the celebrities, influenced by the credibility of the endorsers and also with their expertise. In addition, if the persona of the celebrity is matching with that of the product, customers assume and believe such congruency extra optimistically. Our review adds to the literature in the viewpoint specified previously. On account of administrative suggestions, the organizations which utilize limited time methodologies, especially celebrity endorsement must be cautious while choosing superstar for sustain because our review demonstrates that credibility of endorser's matters a lot for buyers. On the condition that celebrity is well known however not credible, then it won't influence customers' ability to purchase the endorsed product. The promotional strategy of the organization should be designed by looking at the target market and product being advertising, keeping in view the credibility factor.

\section{RESEARCH CONCLUSION AND LIMITATION}

\subsection{Conclusion}

This study is an initial step to show the impact of physical attractiveness of celebrities on buying behavior (purchase intentions). Our results show that the physical appearance of a celebrity 
has an impact on consumer purchase intentions. There are a no different perception from gender, ages, institution type, and education background point of view regarding the attractiveness of celebrity physical and their intention to buy.

\subsection{Limitation}

This study has limitations; it only investigates within the scope of universities in Multan city. Therefore, the result in this study cannot be generalized to represent all the students of Punjab province or Pakistani perspective.

\section{REFERENCES}

Andrews, J. C., \& Shimp, T. A. (2017). Advertising, promotion, and other aspects of integrated marketing communications. Toronto: Nelson Education.

Anjum, B., Dhanda, S. K., \& Nagra, S. (2012). Impact of celebrity endorsed advertisements on consumers. Asia Pacific Journal of Marketing \& Management Review, 1(2), 22-33.

Baker, M. J., \& Churchill Jr, G. A. (1977). The impact of physically attractive models on advertising evaluations. Journal of Marketing research, 14(4), 538-555. https://doi.org/10.1177/002224377701400411.

Caballero, M. J., Lumpkin, J. R., \& Madden, C. S. (1989). Using physical attractiveness as an advertising tool: An empirical test of the attraction phenomenon. Journal of Advertising Research, 29(4), 16-22.

Clow, K. E., James, K. E., Kranenburg, K. E., \& Berry, C. T. (2006). The relationship of the visual element of an advertisement to service quality expectations and source credibility. Journal of Services Marketing, 20(6), 404-411. https://doi.org/10.1108/08876040610691293.

Gaied, A. M., \& Rached, K. S. B. (2010). The persuasive effectiveness of famous and non famous endorsers in advertising. IBIMA Business review.

Ghani, U., \& Kakakhel, T. (2011). The impact of celebrity endorsement on the youth of Pakistan. International Proceedings of Economics Development and Research, Singapore.

Jamil, R. A., \& Rameez ul Hassan, S. (2014). Influence of celebrity endorsement on consumer purchase intention for existing products: a comparative study. Journal of Management Info, 4(1), 1-23. Retrieved from https://ssrn.com/abstract=2566816.

Joseph, W. B. (1982). The credibility of physically attractive communicators: A review. Journal of advertising, 11(3), 15-24. https://doi.org/10.1080/00913367.1982.10672807.

Kahle, L. R., \& Homer, P. M. (1985). Physical attractiveness of the celebrity endorser: A social adaptation perspective. Journal of consumer research,11(4), 954-961. http://dx.doi.org/10.1086/209029.

Krejcie, R. V., \& Morgan, D. W. (1970). Determining sample size for research activities. Educational and psychological measurement, 30(3), 607-610. https://doi.org/10.1177/001316447003000308.

McCormick, K. (2016). Celebrity endorsements: Influence of a product-endorser match on Millennials attitudes and purchase intentions. Journal of retailing and consumer services, 32, 39-45. https://doi.org/10.1016/j.jretconser.2016.05.012. 
McCracken, G. (1989). Who is the celebrity endorser? Cultural foundations of the endorsement process. Journal of consumer research,16(3), 310-321. Retrieved from https://www.jstor.org/stable/2489512.

Ohanian, R. (1990). Construction and validation of a scale to measure celebrity endorsers' perceived expertise, trustworthiness, and attractiveness. Journal of advertising, 19(3), 39-52. https://doi.org/10.1080/00913367.1990.10673191.

Pandey, V. K. (2011). Impact of celebrity endorsement on young Generation through TV Advertisement. VSRD International Journal of Business \& Management Research, 1(10), 226-231.

Parmar, B. K. J., \& Patel, R. P. (2015). Fame versus no name: Gauging the impact of celebrities and non-celebrities endorsement on purchase. African Journal of Business Management, 9(4), 127-133. https://doi.org/ 10.5897/AJBM2014.7589.

Phau, I., \& Lum, L. (2000). Effects of "physical attractiveness" in the evaluation of print advertisements. Asia Pacific Journal of Marketing and Logistics, 12(4), 41-59. https://doi.org/10.1108/13555850010764668.

Rafique, M., \& Zafar, Q. U. A. (2012). Impact of celebrity advertisement on customers' brand perception and purchase intention. Asian Journal of Business and Management Sciences, 1(11), 53-67.

Reingen, P. H., \& Kernan, J. B. (1993). Social perception and interpersonal influence: Some consequences of the physical attractiveness stereotype in a personal selling setting. Journal of Consumer Psychology, 2(1), 25-38. https://doi.org/10.1016/S1057-7408(08)80073-3.

Schiffman, L. G., Kanuk, L. L., \& Hansen, H. (2008). Consumer behaviour: A European outlook. Harlow: Pearson Education Limited.

Till, B. D. (1998). Using celebrity endorsers effectively: lessons from associative learning. Journal of product \& brand management, 7(5), 400-409. https://doi.org/10.1108/10610429810237718.

Till, B. D., \& Busler, M. (2000). The match-up hypothesis: Physical attractiveness, expertise, and the role of fit on brand attitude, purchase intent and brand beliefs. Journal of advertising, 29(3), 1-13. https://doi.org/10.1080/00913367.2000.10673613.

*) Rizwan Khalid, Department of Management Science, COMSATS University Islamabad, Vehari, Pakistan (Email: rizwan3532@gmail.com)

**) Tehreem Yasmeen, Department of Management Science, COMSATS University Islamabad, Vehari, Pakistan (Email: tehreemyasmeen@gmail.com) 